\title{
Implementasi Unit Dosing Iod Pada IKM Garam Konsumsi Beryodium di Desa Gresik Putih, Kecamatan Gapura, Kabupaten Sumenep
}

\author{
Iodine Dosing Unit Implementation in Small And Medium Industries of Iodized \\ Consuming Salt in Gresik Putih Village, Gapura Districts, Sumenep District
}

\author{
Ardhaningtyas Riza U. \\ Baristand Industri Surabaya \\ Kementerian Perindustrian \\ Surabaya \\ riza2308@gmail.com
}

\author{
Deny Suryana \\ Baristand Industri Surabaya \\ Kementerian Perindustrian \\ Surabaya \\ denysuryana.81@gmail.com
}

\begin{abstract}
Abstrak- Pemerintah mempunyai kebijakan untuk memenuhi kebutuhan garam nasional, maka untuk menunjang kebijakan tersebut, industri garam di Indonesia harus meningkatkan kuantitas dan kualitas produk dengan mengacu pada SNI. Permasalahan industri garam saat ini adalah proses iodisasi yang dilakukan secara manual sehingga tidak bisa dikontrol berapa dosis $\mathrm{KIO}_{3}$ yang harus ditambahkan secara tepat dan tidak homogen. Baristand Industri Surabaya telah mendesain unit dosing iod secara otomatis sebagai solusi dari permasalahan yang timbul pada proses iodisasi garam. Unit dosing tersebut dilengkapi dengan switch level sebagai sensor massa dan seperangkat alat dosing iod yang dapat diatur volumenya sesuai dengan massa garam yang masuk pada hooper. Alat juga dilengkapi dengan bak pengaduk dan screw untuk menciptakan homogenitas iod pada produk garam. Unit dosing iod yang dirancang mempunyai dimensi $970 \mathrm{~mm}$ x $420 \mathrm{~mm}$ x $1430 \mathrm{~mm}$ dan kapasitas produksi $60 \mathrm{~kg} / \mathrm{jam}$ rata-rata. Unit dosing iod tersebut telah diuji coba di Desa Gresik Putih, Kecamatan Gapura, Kabupaten Sumenep. Dari hasil implementasi tersebut didapatkan data garam konsumsi beryodium yang dihasilkan telah mempunyai homogenitas yang cukup bagus dengan nilai RSD $0.548 \%$ dan kadar KIO3 berkisar $71.56 \mathrm{mg} / \mathrm{kg}-72.48 \mathrm{mg} / \mathrm{kg}$.
\end{abstract}

Kata Kunci- unit dosing iod, iodisasi, garam konsumsi beryodium, $\mathrm{KIO}_{3}$

Abstract-The government has a policy to fulfill the needs of national salt, so to support this policy, the salt industry in Indonesia must increase the quantity and quality of products by referring to SNI. The problem of the salt industry at this time is that the iodization process is carried out manually so it cannot be controlled how many doses of $\mathrm{KIO}_{3}$ should be added appropriately and not homogeneously. Baristand Industri Surabaya has designed an automatic iod dosing unit as a solution to the problems that arise in the salt iodization process. The dosing unit is equipped with a level switch as a mass sensor and a set of iodine dosing devices whose volume can be adjusted according to the mass of salt entering the hooper. The device is also equipped with a stirring tub and screw to create homogeneity of iodine in salt products. The iod dosing unit designed has dimensions of $970 \mathrm{~mm} \times 420 \mathrm{~mm} \times 1430 \mathrm{~mm}$ and a production capacity of $60 \mathrm{~kg} /$ hour on average. The iod dosing unit has been tested in Gresik Putih Village, Gapura District, Sumenep Regency. From the results of the implementation, it was found that the resulting iodized salt consumption data had quite good homogeneity with an $\mathrm{RSD}$ value of $0.548 \%$ and $\mathrm{KIO}_{3}$ levels ranging from $71.56 \mathrm{mg} / \mathrm{kg}-72.48 \mathrm{mg} / \mathrm{kg}$.

Keywords - iodine dosing unit, iodized, iodized consumption salt, $\mathrm{KIO}_{3}$

\section{PENDAHULUAN}

Pemerintah menargetkan swasembada garam nasional pada tahun 2017 dengan target produksi sebesar 4,6 juta ton. Kebutuhan garam nasional pada 2020 diperkirakan mencapai 4,4 juta ton yang terdiri dari 3.74 juta ton garam industri dan 398 ribu ton garam konsumsi. Untuk mendukung swasembada garam nasional tersebut, maka industri garam nasional juga harus meningkatkan kualitas produk mereka. Produk garam konsumsi harus memenuhi standard SNI $3556: 2010$, dimana kdar $\mathrm{NaCl}$ minimal $94 \%$ dan kadar $\mathrm{KIO} 3$ minimal $30 \%$. Proses iodisasi yang dilakukan di industri garam konsumsi selama ini masih menggunakan cara manual, sehingga tidak bisa dikontrol berapa dosis $\mathrm{KIO}_{3}$ yang harus ditambahkan secara tepat. Seperti yang terjadi di industri garam rakyat di sepanjang pantai utara Jawa Tengah melakukan iodisasi garam dengan memasukkan $\mathrm{KIO}_{3}$ ke dalam ketel kemudian disemprotkan pada garam krosok lalu diaduk dengan skop, selanjutnya dibuat briket [1]. Sistem iodisasi seperti ini menyebabkan kandungan $\mathrm{KIO}_{3}$ dalam briket garam tidak merata, selain itu juga banyak $\mathrm{KIO}_{3}$ yang tercecer $\pm 10 \%$ sehingga terjadi pemborosan [1]. Proses pembuatan garam beryodium secara manual juga ada yang dilakukan dengan cara mengaduk bolak-balik setumpuk garam yang telah disemprotkan larutan iodat ke dalam garam tersebut pada konsentrasi tertentu [2]. Sedangkan proses iodisasi garam skala besar umumnya menggunakan sistem kontinyu dengan cara menyemprotkan larutan $\mathrm{KIO}_{3}$ ke permukaan garam yang berjalan di atas conveyor belt dan langsung dikeringkan dengan menggunakan udara panas [3]. 
Alat iodisasi garam yang dirancang dan diimplelemtasikan ini terdiri dari beberapa bagian, yaitu hopper utama, hopper timbangan (weighing), spray iod, hopper pengaduk (spraying and mixing), screw mixing dan magnet untuk menghilangkan benda asing dalam garam. Teknologi iodisasi garam dengan menggunakan screw conveyor berkapasitas 3-15 Kg telah dilakukan oleh Hermana Suryana, namun homogenisasi garam belum maksimal. Kadar garam yang homogen yaitu $0,5 \%$ $2,75 \%[4]$.

Dimensi unit dosing otomatis adalah $970 \mathrm{~mm} \times 420 \mathrm{~mm} \mathrm{x}$ $1430 \mathrm{~mm}$ dan kapasitas produksi $60 \mathrm{~kg} / \mathrm{jam}$ rata-rata. Spesifikasi motor penggeraknya adalah 1 phase $0.37 \mathrm{KW} \mathrm{3/4}$ HP $1400 \mathrm{rpm}$. Dilengkapi dengan spray refill syringe $1-10 \mathrm{ml}$ dan spray air brush $0,3 \mathrm{~mm}$ [5]. Alat dapat beroperasi dengan baik dan dapat menghasilkan garam beryodium yang homogen. Unit dosing ini dilengkapi dengan hopper spray dan mixing. Alat otomasi iodisasi garam ini dimensinya tidak terlalu besar sehingga dapat diaplikasikan di industri garam konsumsi beryodium yang mempunyai kapasitas produksi tidak lebih dari $60 \mathrm{~kg} / \mathrm{jam}$ rata-rata. Jika industri tertarik untuk menggunakan teknologi tersebut, maka bisa memperbesar dimensi alat tersebut.Unit dosing iod otomatis ini telah diuji coba di lab uji Baristand Industri Surabaya dengan melakukan variasi volume iod yang disemprotkan dan lama waktu mixing. Dari hasil uji coba tersebut didapatkan data yang sama-sama memberikan hasil yang homogen pada waktu pengadukan 60 detik. Spray iod $3 \mathrm{ml}$ memberikan hasil kadar $\mathrm{KIO}_{3}$ dalam garam $40.89 \mathrm{mg} / \mathrm{kg}$ (adbk) dan kadar air 2.82\% ; spray $4 \mathrm{ml}$ memberikan kadar $\mathrm{KIO}_{3}$ rata rata $58.61 \mathrm{mg} / \mathrm{kg}$ (adbk) dan kadar air $2.81 \%$; spray $5 \mathrm{ml}$ memberikan kadar $\mathrm{KIO}_{3}$ rata rata $67.17 \mathrm{mg} / \mathrm{kg}$ (adbk) dan kadar air $3.14 \%$ dan spray $7 \mathrm{ml}$ memberikan kadar $\mathrm{KIO}_{3}$ rata rata $88.2 \mathrm{mg} / \mathrm{kg}$ (adbk) dan kadar air 3,37 \% [5]. Variasi dosing iod menunjukkan bahwa penambahan volume dosing meningkatkan kadar air garam produk namun kenaikannya tidak terlalu signifikan. Kadar air garam yang dihasilkan dari proses iodisasi ini masih memenuhi persyaratan kadar air sesuai SNI $3556: 2010$.

Tujuan dari kegiatanini adalah untuk mengimplementasikan alat / teknologi dosing iod pada industri garam konsumsi beryodium. Dengan demikian maka hasil litbang dari Baristand Industri Surabaya mempunyai manfaat / daya guna bagi industri di sekitarnya. Penerapan teknologi ini diharapkan dapat membantu IKM garam beryodium di daerah penghasil garam untuk menghasilkan garam konsumsi beryodium yang memenuhi syarat SNI 3556 : 2010, terutama dalam hal homogenisasi kandungan $\mathrm{KIO}_{3}$ dan pembubuhan $\mathrm{KIO}_{3}$ dalam jumlah yang tepat, tidak berlebihan dan tidak kekurangan. Dalam jangka panjangnya, kegiatan implementasi ini diharapkan dapat membantu industri kecil garam konsumsi untuk memperoleh sertifikasi SNI. Sehingga petani garam dapat meningkatkan nilai jual dari produk garamnya, mengefisiensikan biaya dan tenaga. Hal ini juga dapat membawa dampak positif bagi taraf sosial ekonomi mereka.

\section{BAHAN DAN METODE}

A. Alat dan Bahan

Peralatan yang digunakan dalam implementasi hasil riset ini antara lain :

- Unit Alat Dosing Iod dengan dimensi 970 mm x 420 mm x $1430 \mathrm{~mm}$ dan kapasitas produksi $60 \mathrm{~kg} / \mathrm{jam}$ rata-rata. Dilengkapi dengan spray refill syringe 1-10 ml dan spray air brush 0,3 mm (Gambar 1)

- Peralatan pendukung lainnya (genset 1 phase $0.37 \mathrm{KW} \mathrm{3/4}$ HP $1400 \mathrm{rpm} /$ instalasai listrik lainnya)

- Timbangan Kasar 5 Kg dan Anak Timbangan 2 Kg

- Neraca analytic

- Labu Ukur 1 L

Sedangkan bahan yang digunakan antara lain :

- Garam bahan baku diambil dari tambak garam Desa Gresik Putih, Kabupaten Sumenep ddengan kadar $\mathrm{NaCl}$ minimal 94\% dan belum mengandung $\mathrm{KIO}_{3}$.

- $\quad$ Air untuk melarutkan $\mathrm{KIO}_{3}$

- $\mathrm{KIO}_{3}$

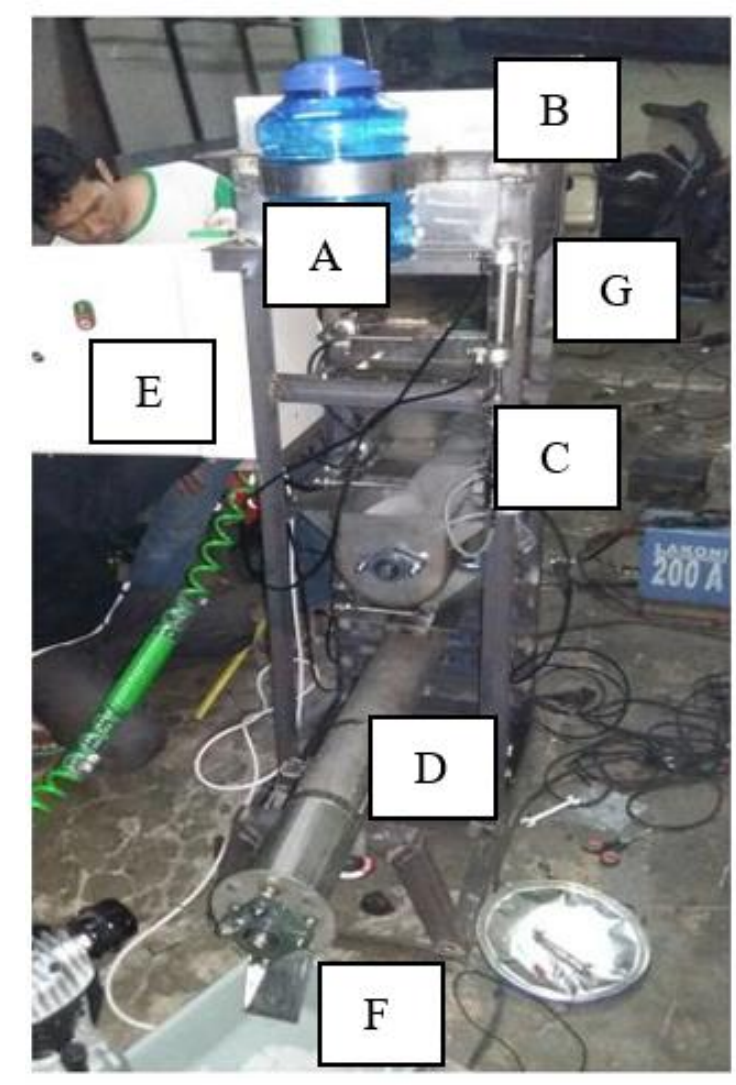

Gambar 1. Unit Dosing Iod Garam Konsumsi Yang Diimplementasikan A. Tabung larutan $\mathrm{KIO} 3$

B. Hopper tempat masuk garam

C. Hopper mixing, tempat penyemprotan $\mathrm{KIO} 3$ dan pengadukan

D. Screw

E. Panel

F. Outlet produk dilengkapi magnet

G. Skala untuk spray KIO3 
Data yang akan diambil dalam kegiatam implemetasi ini adalah kadar $\mathrm{KIO}_{3}, \mathrm{H}_{2} \mathrm{O}, \mathrm{NaCl}$, logam $\mathrm{Cd}, \mathrm{Hg}$ dan Arsen. Metode uji yang digunakan mengacu pada SNI $3556: 2010$.

Bahan yang digunakan untk pengujian $\mathrm{KIO}_{3}$ dalam garam konsumsi beryodium antara lain : air suling, $\mathrm{NaCl}$ p.a, Larutan $\mathrm{KIO}_{3} 0.005 \mathrm{~N}$, Larutan $\mathrm{H}_{3} \mathrm{PO}_{4} 85 \%$, Indikator amylum, Kristal $\mathrm{KI}$, Larutan Baku $\mathrm{Na}_{2} \mathrm{~S}_{2} \mathrm{O}_{3} 0.005 \mathrm{~N}$. Sedangkan peralatan yang digunakan untuk pengujian $\mathrm{KIO}_{3}$ antara lain : Mikroburet 10 $\mathrm{ml}$, Labu Erlenmeyer $300 \mathrm{ml}$, Stirrer, Pipet $5 \mathrm{ml}$, Gelas ukur $100 \mathrm{ml}$.

Bahan yang digunakan untuk pengujian kadar air adalah : sampel garam konsumsi beryodium, sedangkan peralatan yang digunakan untuk pengujian kadar air antara lain : Botol timbang, Oven, esikator, Neraca analitik.

Bahan yang digunakan untuk pengujian $\mathrm{NaCl}$ adalah : Aquadest, $\mathrm{AgNO}_{3} 0,1 \mathrm{~N}, \mathrm{~K}_{2} \mathrm{CrO}_{4} 5 \%$, Kristal magnesium oksida, $\mathrm{MgO}$ atau natrium bikarbonat, Asam nitrat 1:1. Sedangkan peralatan yang digunakan untuk pengujian $\mathrm{NaCl}$ antara lain : Neraca, Buret dengan ketelitian $0,1 \mathrm{ml}$, Erlenmeyer $300 \mathrm{ml}$, Pipet $2 \mathrm{ml}$, Labu ukur $500 \mathrm{ml}$, Gelas piala.

Bahan yang digunakan untuk pengujian logam $\mathrm{Cd}$ antara lain : Aquadest, Asam nitrat $\mathrm{HNO}_{3}$ pekat $65 \%$, Larutan baku Cd dengan konsentrasi $1000 \mu \mathrm{g} / \mathrm{ml}$, Larutan kerja Cd dengan konsentrasi $0 \mu \mathrm{g} / \mathrm{ml} ; 0,25 \mu \mathrm{g} / \mathrm{ml} ; \mu \mathrm{g} / \mathrm{ml} ; 0,5 \mu \mathrm{g} / \mathrm{ml} ; \mu \mathrm{g} / \mathrm{ml}$; $1,0 \mu \mathrm{g} / \mathrm{ml} ; 1,5 \mu \mathrm{g} / \mathrm{ml} ; 2,0 \mu \mathrm{g} / \mathrm{ml}$. Sedangkan peralatan yang digunakan untuk pengujian $\mathrm{Cd}$ antara lain : Spektrofotometer serapan atom (SSA) / AAS, Pipet, Labu ukur $10 \mathrm{ml}, 100 \mathrm{ml}$, $500 \mathrm{ml}$, Penangas air, Gelas ukur kapasitas $10 \mathrm{ml}$, Gelas piala $250 \mathrm{ml}, 400 \mathrm{ml}$

\section{B. Metodologi}

1. Metode Pelaksanaan Implementasi Hasil Litbang

Pelaksanaan implementasi hasil litbang dilakukan melalui beberapa tahapan antara lain :
a. Tahap - 1: Survei Kelayakan Industri.
b. Tahap - 2 : Setting Alat dan penyempurnaan sistem
c. Tahap - 3: Trial dan Uji Proses
d. Tahap -4 : Sosialisasi kepada industri
e. Tahap - 5 : Implementasi
f. Tahap -6 : Monitoring dan pengambilan data
g. Tahap -7 : Pelaporan

\section{Metode Uji $\mathrm{KIO}_{3}$ dalam Garam Konsumsi Beryodium}

- Menimbang garam sebanyak 25 gram, dimasukkan ke dalam erlenmeyer dan dilarutkan dengan air suling sampai $125 \mathrm{ml}$

- Menambahkan 2 ml H3PO4 85\% dan 0,1 gram Kristal KI

- Menitrasi sampel larutan garam dengan Na2S2O3 0,005 N sampai larutan bewaran kuning cerah

- Meneteskan 2 tetes indicator amylum ke dalam sampel hingga larutan berwarna ungu, kemudian menitrasi larutan dengan Na2S2O3 0,005 N sampai larutan berubah warna menjadi bening
Catat volume titrasi Na2S2O3 0,005 N yang digunakan Konsentrasi $\mathrm{KIO}_{3}$ dihitung dengan rumus sebagai berikut :

$$
\begin{aligned}
& \text { Kadar } \mathrm{KIO}_{3}\left(\frac{\mathrm{mg}}{\mathrm{kg}}\right)= \\
& \frac{890 \times \mathrm{Vc}}{\mathrm{W} \times \mathrm{Vst}} \times 100 \% \text { Kadar } \mathrm{KIO}_{3}= \\
& \frac{100}{(100-\text { kadar air })} \times \text { Kadar KIO3 }
\end{aligned}
$$

Dimana :

$\mathrm{Vc}=$ Volume $\mathrm{Na}_{2} \mathrm{~S}_{2} \mathrm{O}_{3}$ yang digunakan untuk menitrasi contoh garam

Vst $=$ Volume $\mathrm{Na}_{2} \mathrm{~S}_{2} \mathrm{O}_{3}$ yang diperlukan untuk standardisasi $(\mathrm{ml})$

$\mathrm{W}=$ Massa contoh garam (gram)

3. Metode Uji Kadar Air dalam Garam Konsumsi Beryodium

- Mengoven botol timbang kosong pada suhu $105^{\circ} \mathrm{C}$ selama 1 jam, kemudian menimbangnya. Sehingga diketahui berat kosong botol timbang $\mathrm{W}_{\mathrm{o}}$

- Menimbang sampel garam ke dalam botol timbang yang telah diketahui berat kosongnya. Sehingga didapatkan berat botol timbang + garam awal, $\mathrm{W}_{1}$

- Mengoven sampel + botol timbang tersebut pada suhu $105^{\circ} \mathrm{C}$ selama 3 jam

- Meletakkan sampel dalam botol timbang yang telah dioven selama 3 jam ke dalam esikator selama 15 menit

- Menimbang sampel dalam botol timbang, sehingga didapatkan $\mathrm{W}_{2}$

- Mengoven kembali sampel dalam botol timbang pada suhu $105^{\circ} \mathrm{C}$ selama 1 jam hingga didapatkan berat $\mathrm{W}_{2}$ konstan

- Rumus yang digunakan untuk menghitung kadar air dalam garam adalah sebagai berikut :

$$
\% \text { kadar air }=\frac{w 1-w 2}{w 1-w o} \times 100
$$

Dimana:

$\mathrm{W}_{1}=$ Berat awal botol + sampel sebelum di oven $($ gram $)$

$\mathrm{W}_{2}=$ Berat akhir botol + sampel setelah di oven (gram)

$\mathrm{W}_{\mathrm{o}}=$ Berat cawan kosong $($ gram $)$

\section{Metode Uji Natrium Clorida ( $\mathrm{NaCl}$ ) dalam Garam Konsumsi Beryodium}

- Menimbang 50 gram contoh garam, menambahkan $200 \mathrm{ml}$ air suling, mengaduknya kemudian menyaringnya dan ditampung dalam labu $500 \mathrm{ml}$.

- Membilas larutan tersebut dengan akuadest dan mengimpitkannya sampai tanda garis (larutan A)

- Memipet $2 \mathrm{ml}$ larutan A ke dalam Erlenmeyer $250 \mathrm{ml}$

- Mengasamkan larutan tersebut dengan asam nitrat 1:1 sampai larutan bereaksi asam terhadap indicator metil merah

- Menetralkan larutan dengan $\mathrm{MgO}$ atau $\mathrm{NaHCO}_{3}$

- Mengencerkan dengan air suling sampai $100 \mathrm{ml}$

- Menambahkan $1 \mathrm{ml}$ larutan $\mathrm{K}_{2} \mathrm{CrO}_{4}$

- Menitrasi dengan larutan $\mathrm{AgNO}_{3}$ 0,1 N sampai terbentuk warna merah bata 
- Catatat volume titrasi. Rumus yang digunakan untuk menghitung $\mathrm{NaCl}$ adalah sebagai berikut :

$$
\% \text { kadar } \mathrm{NaCl}=\frac{V \times N \times f p \times 58,5}{w} \times 100 \%
$$

$$
\begin{aligned}
& \text { Dimana: } \\
& \mathrm{V}=\text { Vol titrasi AgNO3 0,1 N (ml) } \\
& \mathrm{N}=\text { Normalitas AgNO3 } \\
& \mathrm{Fp}=\text { factor pengenceran } \\
& \mathrm{W}=\text { Berat garam }(\mathrm{mg})
\end{aligned}
$$

\section{Metode Uji Logam Cadmium (Cd) dalam Garam Konsumsi Beryodium}

- Menimbang 10 gram sampel garamke dalam gelas piala $400 \mathrm{ml}$. Melarutkan sampel tersebut dengan $100 \mathrm{ml}$ akuadest

- Menambahkan HNO3 ke dalam larutan tersebut sampai pH $<2$

- Memasukkan larutan kedalam labu ukur 500 ml, mengimpitkan sampai tanda garis dan mengocoknya

- Membuat deret standard untuk kurva kalibrasi dan larutan blanko

- Membaca larutan tersebut dengan menggunakan SSA

\section{HASIL DAN PEMBAHASAN}

\section{A. Tahap Survei Kelayakan Industri}

Survei kelayakan industri mulai dilakukan pada awal bulan Februari 2017. Parameter yang mempengaruhi survei kelayakan industri sebagai tempat implementasi alat iodisasi antara lain: merupakan daerah centra industri garam, merupakan daerah yang terpencil, belum memiliki teknologi iodisasi yang baik, belum mendapatkan sertifikasi SNI dan mau menerapkan teknologi yang diimplementasikan. Dari pertimbangan tersebut, maka didapatkan daerah centra garam yang akan mengimplementasikan teknologi ini, yaitu koperasi garam di Desa Gresik Putih, Kecamatan Gapura, Kabupaten Sumenep. Kunjungan ke lokasi implemetasi dilakukan pada tanggal 2 Agustus 2017, Koperasi garam tersebut telah memiliki badan hukum (sertifikat terlampir). Kapasitas produksi $60 \mathrm{~kg} / \mathrm{hari}$. Proses pembuatan garam selama ini dilakukan secara manual dan sederhana, tanpa menggunakan bantuan mesin. Produk garam yang diproduksi belum mendapatkan sertifikat SNI $3556: 2010$.

\section{B. Tahap Setting Alat dan Penyempurnaan Sistem}

Setting dan penyempurnaan alat dilakukan pada bulan Maret 2017. Alat mengalami penyumbatan pada lubang spray dan inject / dosing iod. Hal ini disebabkan karena alat tidak pernah diuji coba / digunakan lagi setelah selesai running pengambilan data penelitian awal, sehingga larutan iod mengkristal dan menyumbat saluran tersebut. Lubang spray / inject dosing iod dicuci dengan menggunakan ultrasonic sehingga dapat berfungsi kembali dengan baik. Selain membersihkan sumbatan pada lubang spray, juga dilakukan perbaikan system pengabutan $\mathrm{KIO}_{3}$. Pada saat pengambilan data penelitian awal (2016), terjadi kendala ketika melakukan spray iod pada volume diatas $3 \mathrm{ml}$. Pengabutan tidak terjadi dengan baik ketika inject iod dilakukan pada volume $4 \mathrm{ml}, 5$ $\mathrm{ml}$ dan $7 \mathrm{ml}$. Bahkan cairan $\mathrm{KIO}_{3}$ tumpah dari wadah spray. Maka dilakukan perbaikan pada system spray $\mathrm{KIO}_{3}$ supaya dapat berfungsi dengan baik pada volume antara $3 \mathrm{ml}-10 \mathrm{ml}$. Alat berfungsi sesuai dengan seting awal penelitian, karena tidak mengalami penambahan / pengembangan system.

\section{Tahap Trial dan Uji Proses}

Trial dan uji proses dilakukan pada bulan Mei Oktober 2017. Setelah saluran dosing iod dibersihkan dari penyumbatan dan dilakukan perbaikan system spray inject $\mathrm{KIO}_{3}$, makadilakukan trial terhadap proses dan pengambilan data untuk inject $4 \mathrm{ml}, 5 \mathrm{ml}$ dan $7 \mathrm{ml}$. Pengambilan data tersebut dilakukan karena adanya kendala system spray pada saat penelitian awal. Hasil trial menunjukkan bahwa alat dapat berfungsi dengan baik, mulai dari otomatisasi hopper, bak mixing dan screw. Motor dan sistem berjalan baik. Berikut ini adalah alur proses operasional unit dosing iod :

Garam bahan baku dimasukkan ke dalam hopper utama, kemudian akan dikeluarkan ke dalam wadah timbangan yang telah dilengkapi dengan sensor massa. Ketika garam sudah memenuhi massa yang dikehendaki, maka katup hopper utama akan tertutup secara otomatis. Kemudian garam akan masuk ke wadah mixing dan disemprot dengan iod. Volume iod yang disemprotkan ke dalam wadah mixing telah disesuaikan dengan massa garam yang masuk ke dalam hopper timbangan. Setelah itu garam akan dimixing di wadah mixing, kemudian garam akan melewati screw mixed untuk sampai pada outlet. Lama waktu mixing bisa diatur. Garam yang keluar akan melewati magnet yang berfungsi untuk menangkap benda asing / impurities yang ada pada garam [4]. Setelah itu garam yang keluar dari proses tersebut akan diuji di laboratorium dengan menggunakan metode SNI 3556 : 2010. Setelah alat berfungsi dengan baik, alat di kirim ke sentra garam di Desa Gresik Putih, Sumenep, pada tanggal 28 Oktober 2017. 


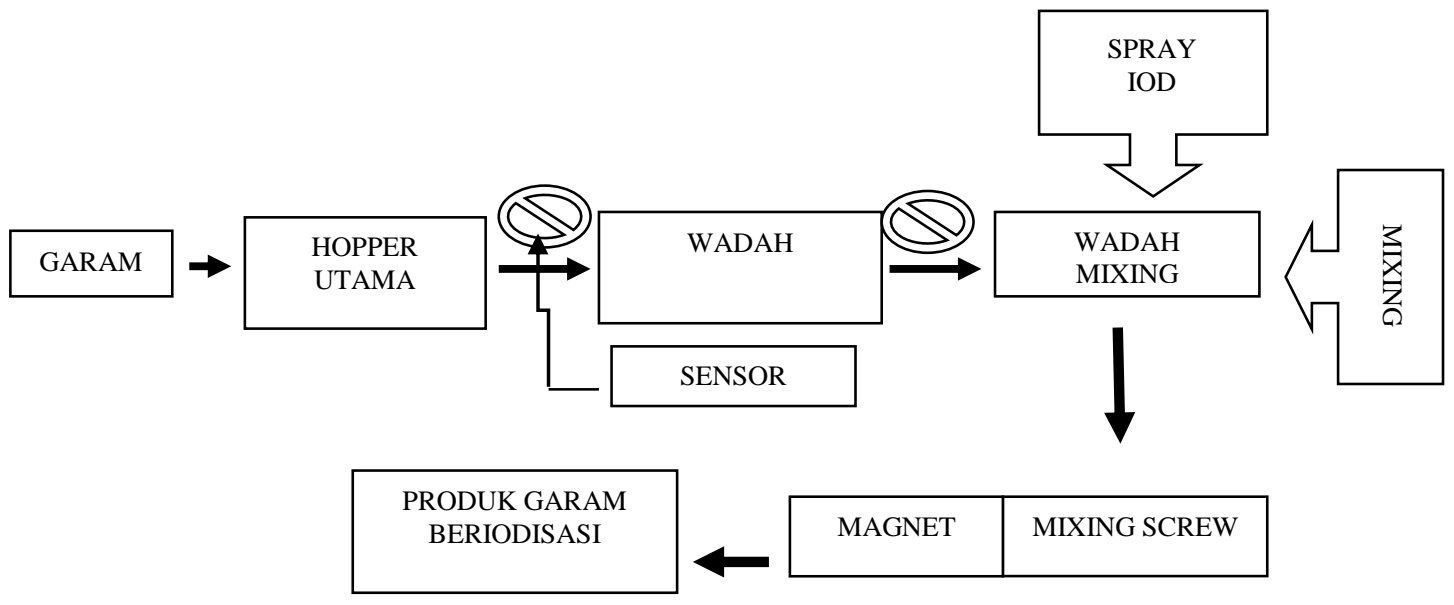

Gambar 2. Diagram Alir Proses Operasi Unit Dosing Iod Otomatis

\section{Sosialisasi Kepada Industri}

Sosilaisasi kepada industri diselenggarakan di Sumenep pada tanggal 31 Oktober 2017. Sosialisasi tersebut meliputi pengenalan alat, bagian-bagiannya dan juga cara mengoperasikan dan merawatnya. Selain itu juga dilakukan sosialisasi mengenai cara mendapatkan sertifikasi SNI produk garam konsumsi beryodium (SNI 3556:2010) dan cara melakukan pengujian kadar $\mathrm{KIO}_{3}$ sesuai metode SNI 3556 : 2010. Sosialisasi dilakukan di auditorium Universitas Wiraraja Sumenep dan di Balai Desa Gresik Putih, Sumenep.

\section{E. Implementasi}

Implementasi alat iodisasi garam dimulai pada tanggal 31 Oktober 2017. Alat tersebut dipergunakan oleh sekelompok anggota koperasi garam di Desa Gresik Putih Sumenep. Implementasi ini diharapkan dapat membantu petani garam di Desa Gresik Putih untuk memproduksi garam yang memenuhi syarat SNI. Berikut ini adalah beberapa dokumentasi pada saat penyerahan alat iodisasi pada koperasi garam di Desa Gresik Putih :
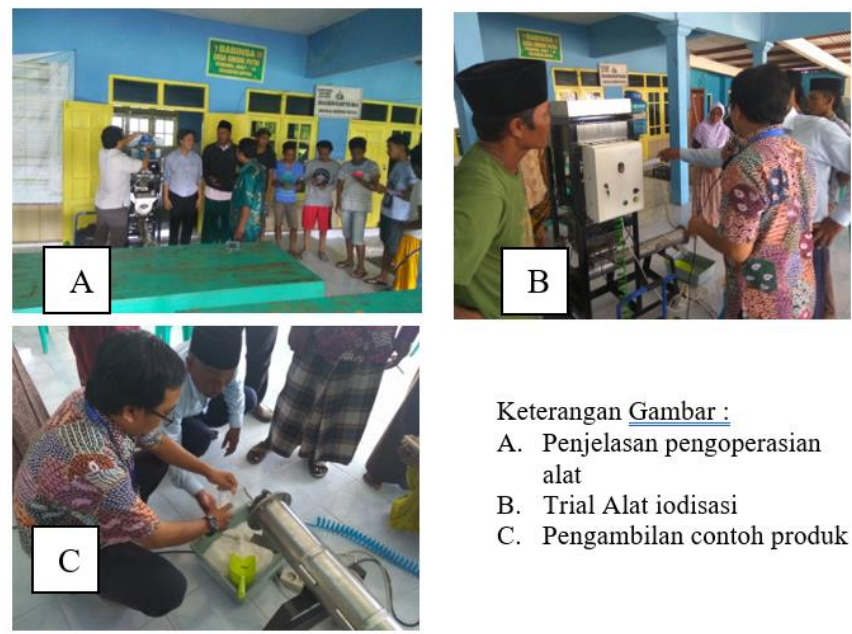

Keterangan Gambar :

A. Penjelasan pengoperasian alat

B. Trial Alat iodisasi

C. Pengambilan contoh produk

Gambar 3. Serah Terima Alat Iodisasi Garam Dan Uji Cobanya

\section{F. Monitoring dan Pengambilan Data}

Monitoring dan pengambilan data dilakukan setelah alat diserahkan dan diimplementasikan. Metode yang digunakan selama kegiatan monitoring adalah wawancara via telepon maupun kunjungan lapangan. Setiap kegiatan kunjungan lapangan dilakukan pengambilan contoh terhadap produk garam yang dihasilkan dari alat tersebut dan dilakukan pengujian laboratorium untuk mengetahui kelayakan kualitasnya. Pada saat implementasi dan uji coba awal, dilakukan produksi garam konsumsi beryodium dan pengambilan sampel produk garam tersebut.

Larutan $\mathrm{KIO}_{3}$ dibuat dengan melarutkan 50 gram KIO3 ke dalam 1 liter air [6].Kemudian spray dilakukan dengan menyemprotkan $5 \mathrm{ml}$ larutan $\mathrm{KIO}_{3}$ ke dalam takaran hopper garam alat tersebut $\left( \pm 2 \mathrm{~kg}\right.$ ). Berikut ini adalah hasil uji $\mathrm{KIO}_{3}$ dalam sampel garam tersebut :

Tabel 1.Kadar Iod pada Saat Uji Coba Awal

\begin{tabular}{cccc}
\hline Kode sampel & Satuan & Kadar KIO3 & CVhorwitz \\
\hline A & $\mathrm{Mg} / \mathrm{kg}$ & 67.03 & \multirow{2}{*}{8.49} \\
\hline $\mathrm{B}$ & $\mathrm{Mg} / \mathrm{kg}$ & 67.23 & \\
\hline
\end{tabular}

Tabel 2.Perhitungan Koefisien Varian

\begin{tabular}{ccc}
\hline No. & kadar iod & $(\mathbf{X}-\mathbf{X r})^{\wedge} \mathbf{2}$ \\
\hline 1 & 67.03 & 4493.02 \\
\hline 2 & 67.23 & 4519.87 \\
\hline Rata-2 $(\mathrm{Xr})$ & - & 67.130 \\
\hline $\mathrm{SD}$ & - & 0.141 \\
\hline$\%$ RSD & $=\mathrm{SD} / \mathrm{rata} 2 * 100 \%$ & 0.211 \\
\hline $\mathrm{CV}_{\text {horwitz }}$ & $=2 \mathrm{e}(1-0,5 \log \mathrm{C})$ & 8.495 \\
\hline $0.5 \mathrm{CV}_{\text {horwitz }}$ & $=0.5 * \mathrm{CV}_{\text {horwitz }}$ & 4.247 \\
\hline Keberterimaan & & DITERIMA
\end{tabular}

Kadar $\mathrm{KIO}_{3}$ rata rata yang didapatkan dari Tabel 1 adalah $67.13 \mathrm{mg} / \mathrm{kg}$. kadar ini memenuhi persyaratan $\mathrm{KIO}_{3}$ sesuai SNI 3556 : 2010, yaitu minimal $30 \mathrm{mg} / \mathrm{kg}$. Jika data $\mathrm{KIO}_{3}$ tersebut dihitung coevisien variance nya (Tabel 2), maka didapatkan nilai \% RSD $<0,5 \mathrm{CV}$ horwitz. Hal ini menunjukkan bahwa kedua data tersebut homogen. 
Kegiatan monitoring dilakukan sebulan setelah serah terima alat. Dalam kegiatan tersebut dilakukan pengambilan beberapa contoh garam hasil produksi koperasi tersebut dengan menggunakan unit dosing iod otomatis. Tabel 3 menunjukkan data hasil ujilaboratorium terhadap sampel yang diambil pada saat monitoring. Sampel tersebut diambil dalam interval waktu tertentu. Dari tabel 3 dapat diketahui bahwa kadar $\mathrm{KIO}_{3}$ sampel A adalah 71,56 mg/kg, sampel $\mathrm{B}=72,48$ $\mathrm{mg} / \mathrm{kg}$, sampel C =72,26 mg/kg dan sampel D =72,01 mg/kg.

Pengujian $\mathrm{KIO}_{3}$ terhadap sampel tersebut dilakukan untuk mengetahui kemampuan unit dosing iod dalam menghasilkan produk garam konsumsi beryodium yang homogen kandungan $\mathrm{KIO}_{3}$ nya.

Tabel 3.Hasil Uji Kualitas Garam yang Diambil pada Saat Monitoring

\begin{tabular}{|c|c|c|c|c|c|c|c|}
\hline \multirow{2}{*}{ Parameter } & \multirow{2}{*}{ Satuan } & \multicolumn{4}{|c|}{ Hasil Uji } & \multirow{2}{*}{$\begin{array}{c}\text { Syarat Mutu SNI } \\
\text { 3556:2010 }\end{array}$} & \multirow{2}{*}{ Kesimpulan } \\
\hline & & A & $\mathrm{B}$ & $\mathrm{C}$ & $\mathrm{D}$ & & \\
\hline Kadar Air $\left(\mathrm{H}_{2} \mathrm{O}\right)$ & $\%(\mathrm{~b} / \mathrm{b})$ & 0.483 & 0.534 & 0.641 & 0.5876 & Maks 7 & Memenuhi standard \\
\hline Kadar $\mathrm{NaCl}$ & $\%(\mathrm{~b} / \mathrm{b})$ & 94.22 & 94.0 & 94.19 & 94.00 & Min 94 & Memenuhi standard \\
\hline Kalium Iodidat (KIO) & $\mathrm{mg} / \mathrm{Kg}$ & 71.56 & 72.48 & 72.26 & 72.01 & Min 30 & Memenuhi standard \\
\hline Cadmium $(\mathrm{Cd})$ & $\mathrm{mg} / \mathrm{Kg}$ & $<0.0024$ & $<0.0024$ & $<0.0024$ & $<0.0024$ & Maks 0.5 & Memenuhi standard \\
\hline Raksa $(\mathrm{Hg})$ & $\mathrm{mg} / \mathrm{Kg}$ & 0.04035 & 0.03405 & 0.0543 & 0.04105 & Maks 0.1 & Memenuhi standard \\
\hline Arsen (As) & $\mathrm{mg} / \mathrm{Kg}$ & $<0.0008$ & $<0.0008$ & $<0.0008$ & $<0.0008$ & Maks 0.1 & Memenuhi standard \\
\hline
\end{tabular}

Tabel 4. Perhitungan Koefisien Varian $\mathrm{Kio}_{3} \mathrm{Hasil}$ Monitoring

\begin{tabular}{ccc}
\hline No. & Kadar Iod & $(\mathbf{X}-\mathbf{X r})^{\wedge} \mathbf{2}$ \\
\hline 1 & 71.56 & 5120.83 \\
\hline 2 & 72.48 & 5253.35 \\
\hline 3 & 72.26 & 5221.51 \\
\hline 4 & 72.01 & 5185.44 \\
\hline Rata-2 $(\mathrm{Xr})$ & - & 72.078 \\
\hline $\mathrm{SD}$ & - & 0.395 \\
\hline \% RSD & $=\mathrm{SD} / \mathrm{rata} 2 * 100 \%$ & 0.548 \\
\hline $\mathrm{CV}_{\text {horwitz }}$ & $=2 \mathrm{e}(1-0,5 \log )$ & 8.404 \\
\hline $0.5 \mathrm{CV}_{\text {horwitz }}$ & $=0.5 * \mathrm{CV}_{\text {horwitz }}$ & 4.202 \\
\hline keberterimaan & $\%$ RSD $\leq 0.5 \mathrm{CV}_{\text {horwitz }}$ & DITERIMA \\
\hline
\end{tabular}

Dari Tabel 4 didapatkan \%RSD $<0.5 \mathrm{CV}$ horwitz, hal ini menunjukkan tidak adanya perbedaan yang signifikan terhadap hasil pengujian $\mathrm{KIO}_{3}$. Sehingga dapat dikatakan bahwa $\mathrm{KIO}_{3}$ yang dihasilkan dengan menggunakan alat tersebut sudah cukup homogen.

Adanya unit dosing iod secara otomatis ini diharapkan bisa menjadi solusi bagi permasalahan homogenisasi $\mathrm{KIO}_{3}$ dalam proses produksi garam konsumsi beryodium. Keberhasilan fortifikasi iod ke dalam produk garam konsumsi diharapkan dapat mengatasi berbagai gangguan yang timbul akibat kekurangan yodium (GAKI), misalnya membesarnya kelenjar tiroid, gangguan mental/pertumbuhan dan kecerdasan [10].

\section{KESIMPULAN}

Unit dosing iod yang dirancang telah diuji dan dapat menghasilkan produk garam beryodium yang homogen dan memenuhi persyaratan SNI 3556 : 2010. Alat ini didesain dengan motor penggerak 1 phase, power $0,37 \mathrm{KW} 3 / 4 \mathrm{HP}$, daya 220 volt dan putaran $1400 \mathrm{rpm}$. Kapasitas produksinya adalah $60 \mathrm{~kg} / \mathrm{jam}$ rata-rata. Adanya alat ini dapat membantu dan mempermudah IKM garam konsumsi beryodium untuk melakukan proses iodisasi secara otomatis, sehingga dapat menghasilkan produk yang homogen dan memenuhi persyaratan SNI 3556 : 2010. Penggunaan alat ini dapat mengurangi biaya operasional, karena tidak terjadi pemborosan penggunaan KIO3, selain itu penggunaan alat ini dapat mengurangi tenaga kerja yang biasa digunakan untuk iodisasi, selain itu produk yang dihasilkan dalam sehari juga lebih banyak bila dibandingkan dengan proses pembuatan garam konsumsi beryodium secara manual.

\section{UCAPAN TERIMAKASIH}

Ucapan terima kasih ditujukan kepada Ibu kepala BARISTAND Industri Surabaya, Ibu Siti Rohmah Siregar, Ibu Fatimah, saudara Yossy Ryananta, Handaru B.C, Sri Rohmawanto, Angger, Nanda L dan semua pihak yang telah membantu terlaksananya kegiatan implementasi hasil riset ini. Selain itu kami juga mengucapkan terimakasih kepada dewan redaksi majalah sehingga tulisan ini dapat diterbitkan.

\section{DAFTAR PUSTAKA}

[1] Wisnu Broto, Heny Kusumayanti, Perbaikan Proses Iodisasi Garam Dengan Sistem Injeksi Di Kabupaten Pati, Program Diploma III Teknik Kimia, Fakultas Teknik, Uinversitas Diponegoro, Semarang.

[2] Ilham M.Z, Sabri, Arsyad A, 2009, Rancang Bangun Mesin Iodisasi Garam Berpengaduk, Laporan Tugas Akhir, Program Studi Teknik Mesin Politeknik Negeri Ujung Pandang, Makasar.

[3] Holman JCM, McCartney W, 1960, Iodized Salt, Chilean Iodine Educational Bureau London

[4] Ardhaningtyas Riza Utami, 2016, Laporan Teknis Penelitian Perencanaan Otomatisasi Unit Dosing Iod Untuk Ik\KM Garam Konsumsi Beryodium, Balai Riset dan Standardisasi Industri Surabaya

[5] www.bppp-tegal.com, Artikel Pembuatan Garam Beryodium, diakses pada tanggal 23 Maret 2016 Pukul 14.15 WIB.

[6] Hermana Suryana, Almasyhuri, Teknologi Yodisasi Garam Untuk Digunakan di Daerah Gangguan Akibat Kurang Yodium, Penelitian Gizi dan Makanan 1996, Balitbangkes Kemendag, No DOI : 10.22435/pgm.V0i0.2310

[7] SNI 3556-2010 Garam Konsumsi Beryodium

[8] Naomi Lestari, Aplikasi GMP dalam Produksi Garam Konsumsi Beryodium, Jurnal Riset Teknologi Industri, Vol 2 No 3, Juni 2008, No DOI : http://dx.doi.org/10.26578/jrti.V2i3.1402

[9] Lutfi Amanati, Karakteristik Kandungan KIO3 pada Garam Konsumsi Beryodium yang Beredar di Kota Blitar, Jurnal Teknologi Proses dan Inovasi Industri, Vol 2 No, 2, November 2017, No DOI : http://dx.doi.org/10.36048/jtpii.V2i2.3506

[10] Siagian A, 2003, Pendekatan Fortifikasi Pangan Untuk Mengurangi Masalah Kekurangan Zat Gizi Mikro, Fakultas Kesehatan Masyarakat Universitas Sumatra Utara 
[11] Retno Hartati, Edy Supriyo, Muhammad Zainury, Yodisasi Garam Rakyat Dengan Sistem Screw Injection, Gema Teknologi Vol 17 No. 4 Periode Oktober 2013-April 2014.
[12] Mahlinda dan Lancy Maurina, 2013, Rancang Bangun Peralatan Iodisasi Garam Portabel Menggunakan Sistem Semi Otomatis, Jurnal Hasil Penelitian Industri, Aceh 